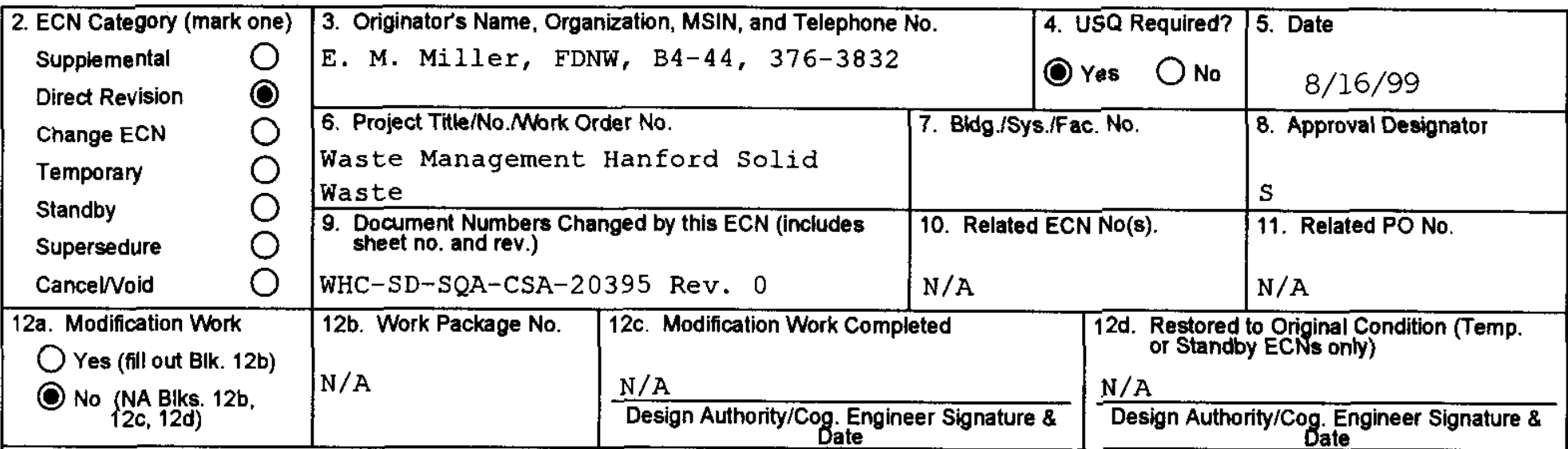

13a. Description of Change

13b. Design Baseline Document? $\bigcirc$ Yes $O$ No

Language in the CSER was revised to make it more precise to resolve comments in Part $B$ of

Waste Management CSER Review Team Report, February 1999.

\begin{tabular}{|ll|}
\hline 14a. Justification (mark one) \\
Criteria Change & \\
Design improvement & \\
Environmental & \\
Facility Deactivation & \\
As-Found & $\bigcirc$ \\
Facilitate Const. & $\bigcirc$ \\
Const. Error/Omission & $\bigcirc$ \\
Design Error/Omission & $\mathrm{O}$
\end{tabular}

15. Distribution (include name, MSIN, and no. of copies)

See distribution list.

1999.

0 14b. Justification Details

Language in the CSER was revised to make it more precise to resolve

$O$ comments in Part $B$ of Waste Management CSER Review Team Report, February 


\section{ENGINEERING CHANGE NOTICE}

16. Design Verification Required

Ores

O No

17. Cost Impact
ENGINEERING
Additional $\bigcirc$
Savings $\bigcirc$

Page 2 of 2

\section{CONSTRUCTION}

Additional $\bigcirc \$$

Savings $\bigcirc \$$
1. ECN (use no. from pg. 1) 638723

18. Schedule Impact (days)

Improvement

Delay

19. Change Impac Review: Indicate the related documents (other than the engineering documents identified on Side 1) that will be affected by the change described in Block 13. Enter the affected document number in Block 20

SDD/DD

Functional Design Criteria

Operating Specification

Criticality Specification

Conceptual Design Report

Equipment Spec.

Const. Spec.

Procurement spec.

Vendor Information

OM Manual

FSAR/SAR

Safety Equipment List

Radiation Work Permit

Environmental Impact Statement

Environmental Report

Environmental Permit $\square$
$\square$
$\square$
$\square$
$\square$
$\square$
$\square$
$\square$
$\square$
$\square$
$\square$
$\square$
$\square$
$\square$
$\square$
$\square$
Seismic/Stress Analysis

Stress/Design Report

Interface Control Drawing

Calibration Procedure

Installation Procedure

Maintenance Procedure

Engineering Procedure

Operating Instruction

Operating Procedure

Operational Safety Requirement

IEFO Drawing

Cell Arrangement Drawing

Essential Material Specification

Fac. Proc. Samp. Schedule

Inspection Plan

Inventory Adjustment Request
Tank Calibration Manual

Health Physics Procedure

Spares Multiple Unit Listing

Test Procedures/Specification

Component Index

ASME Coded Iterm

Human Factor Consideration

Computer Software

Electric Circuit Schedule

ICRS Procedure

Process Control Manual/Plan

Process Flow Chart

Purchase Requisition

Tickler File

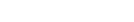

20. Other Affected Documents: (NOTE: Documents listed below will not be revised by this ECN.) Signatures below indicate that the signing organization has been notified of other affected documents listed below.

Document Number/Revision

Document Number/Revision

Document Number/Revision

CPS-SW-149-00002

CPS-SW-149-00003

WRAP 1-CPS-001

21. Approvals

Signature

Design Authority J.R. Rosser /Nath

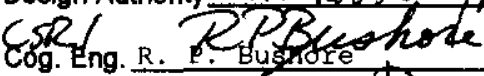

T4-56

Cog. Mgr. R. J. Nicklasts $(\mathrm{k} / 2-\mathrm{T4-56}$

QA

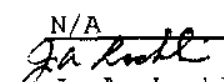

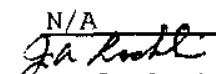

Safety J.A. Locklair

T3-06

Environ. N/A

Other

Eduat 5n. Thale $3 / 12 / 99$

orig. Eng. E. M. Miller ${ }^{2}$ B4-44 Ftozen $107 \mathrm{CL}_{2}$

Orig. Mgr. H.oToffer

Tech. Reyiew J.Greenbor 812999 B4-44

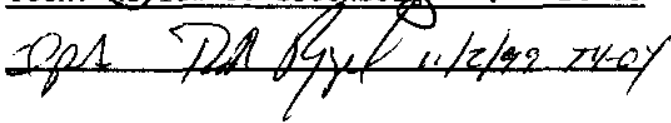

Date
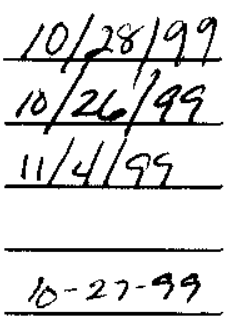

Signature

Design Agent

PE

QA

Safety

Design

Environ.

Other

\section{DEPARTMENT OE ENERGY}

Signature or a Control Number that tracks the Approval Signature

ADDITIONAL 


\begin{tabular}{|c|c|c|c|c|c|}
\hline \multicolumn{6}{|c|}{ DISTRIBUTION SHEET } \\
\hline \multirow{2}{*}{$\begin{array}{l}\text { To } \\
\text { Distribution List }\end{array}$} & \multirow{2}{*}{\multicolumn{3}{|c|}{\begin{tabular}{|l} 
From \\
FDNW Criticality and Shielding
\end{tabular}}} & \multicolumn{2}{|l|}{ Page 1 of 1} \\
\hline & & & & \multicolumn{2}{|l|}{ Date $12 / 03 / 99$} \\
\hline \multirow{2}{*}{\multicolumn{4}{|c|}{$\begin{array}{l}\text { Project Title/Work Order } \\
\text { CSER 95-007: Acceptability of Bettis Laboratories Waste Shipment to WHC Solid } \\
\text { Waste, Rev. 1 }\end{array}$}} & \multicolumn{2}{|l|}{ EDT No. N/A } \\
\hline & & & & \multicolumn{2}{|c|}{ ECN No. 638723} \\
\hline Name & MSIN & $\begin{array}{c}\text { Text } \\
\text { With All } \\
\text { Attach. }\end{array}$ & $\begin{array}{l}\text { Text } \\
\text { Only }\end{array}$ & $\begin{array}{c}\text { Attach./ } \\
\text { Appendix } \\
\text { Only } \\
\end{array}$ & $\begin{array}{c}\text { EDT/ECN } \\
\text { Only }\end{array}$ \\
\hline \multicolumn{6}{|l|}{ Waste Management Project } \\
\hline M. D. Aichele & $\mathrm{T} 4-04$ & $\mathrm{x}$ & & & \\
\hline R. P. Bushore & T4-56 & $\mathrm{X}$ & & & \\
\hline M. F. Hackworth & T4-51 & $x$ & & & \\
\hline J. O. Hanley & T4-05 & & & & $\mathrm{x}$ \\
\hline J. A. Locklair & T3-06 & $\mathrm{X}$ & & & \\
\hline R. J. Nicklas & $\mathrm{T} 4-56$ & & & & $\mathrm{X}$ \\
\hline D. R. Pyzel & $\mathrm{T} 4-04$ & $\mathrm{x}$ & & & \\
\hline J. R. Rosser & $\mathrm{T} 4-03$ & $\mathrm{X}$ & & & \\
\hline \multicolumn{6}{|l|}{ DOE-RL } \\
\hline S. J. Altshuler (ABD) & R3-79 & $\mathrm{X}$ & & & \\
\hline L. T. Nirider (ABD) & A5-55 & $\mathrm{X}$ & & & \\
\hline T. A. Shrader (WMD) & R3-81 & $\mathrm{x}$ & & & \\
\hline \multicolumn{6}{|l|}{ Fluor Daniel Hanford } \\
\hline S. T. Almodovar & A3-02 & $\mathrm{x}$ & & & \\
\hline \multicolumn{6}{|l|}{ Fluor Daniel Northwest } \\
\hline C. S. Eberle & B4-44 & $\mathrm{X}$ & & & \\
\hline J. Greenborg & B4-44 & $\mathrm{x}$ & & & \\
\hline L. L. Reetz (3) & B4-45 & $\mathrm{x}$ & & & \\
\hline G. L. Koci & B4-09 & $\mathrm{x}$ & & & \\
\hline E. M. Miller & B4-44 & $\mathrm{x}$ & & & \\
\hline H. Toffer & B4-44 & $\mathrm{X}$ & & & \\
\hline Central Files (Orig +2 ) & B1-07 & $\mathrm{x}$ & & & \\
\hline Docket Files ( 2 copies) & A3-02 & $\mathrm{x}$ & & & \\
\hline
\end{tabular}




\title{
CSER 95-007: Acceptability of Bettis Laboratories Waste Shipment to WHC Solid Waste
}

\author{
E. M. Miller \\ Fluor Daniel Northwest, Inc. \\ Richland, WA 99352 \\ U.S. Department of Energy Contract DE-AC06-96RL13200 \\ EDT/ECN: 638723 \\ UC: $\quad$ N/A \\ Org Code: 32900 \\ Charge Code: 101607 AJ60/TO 4740-2 \\ B\&R Code: EW7002010 \\ Total Pages: 8
}

Key Words: Central Waste Complex, criticality, safety

Abstract: The purpose of this document is to evaluate a potential discrepancy between the Solid Waste Management (SWM) criticality prevention specifications and a proposed receipt from Bettis Laboratories. The analysis has been performed to determine the acceptability of the Bettis Laboratories waste container with respect to SWM criticality requirements.

TRADEMARK DISCLAIMER. Reference herein to any specific commercial product, process, or service by trade name, trademark, manufacturer, or otherwise, does not necessarily constitute or imply its endorsement, recommendation, or favoring by the United States Government or any agency thereof or its contractors or subcontractors.

Printed in the United States of America. To obtain copies of this document, contact: Document Control Services, P.O. Box 950, Mailstop H6-08, Richland WA 99352, Phone (509)
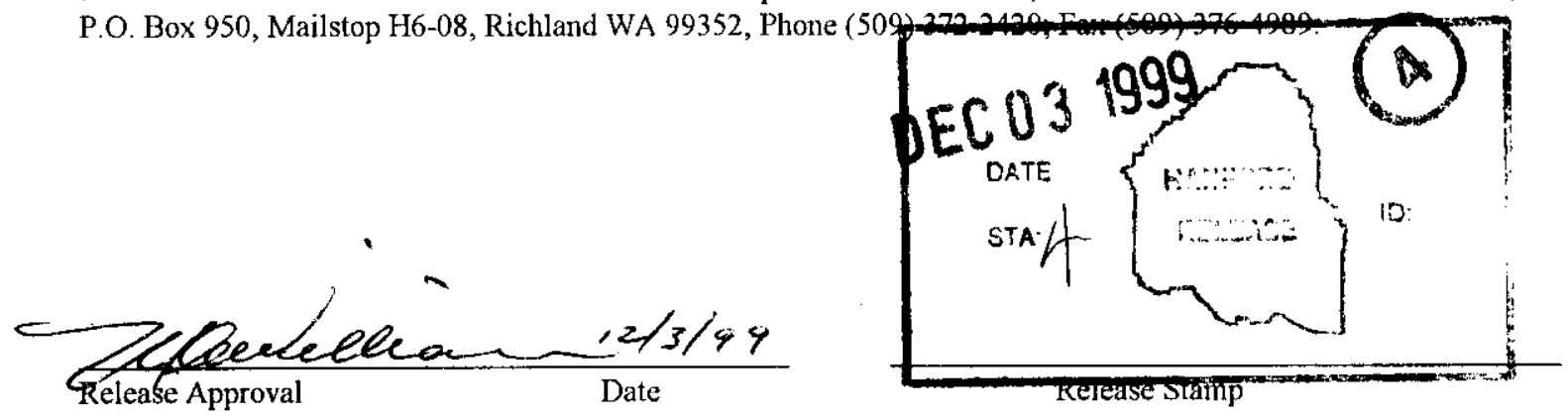
RECORD OF REVISION

\begin{tabular}{|l|l}
\hline $\begin{array}{l}\text { (1) Document Number } \\
\text { HNF-SD-SQA-CSA-20395 }\end{array}$ & Page 1 \\
\hline
\end{tabular}

(2) Title

CSER 95-007: Acceptability of Bettis Laboratories Waste Shipment to WHC Solid Waste

Change Control Record

(3) Revision

(4) Description of Change - Replace, Add, and Delete Pages

(7)

$0 \quad$ Initial release, EDT 608918, dated 4/20/95

1 RS Replace entire document WHC-SD-SQA-CSA-20395 per ECN 638723
Authorized for Release

\begin{tabular}{l|l} 
(5) Cog. Engr. & (6) Cog. Mgr. \\
\hline
\end{tabular}

KM McDonald DB Powell $4 / 20 / 95$

R. PQuothen R.for. Nigklas

Bushore 
HNF-SD-SQA-CSA-20395, Rev. 1

Page 1

CSER 95-007

Title: ACCEPTABILITY OF BETTIS LABORATORIES WASTE SHIPMENT TO WHC SOLID WASTE

Prepared by: Equond im Mnden E. M. Miller, Criticality \& Shielding

Date: 12 AvG 99

Reviewed by:

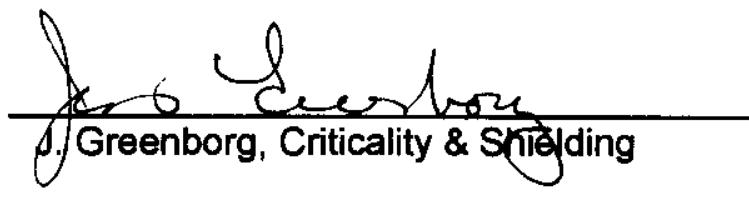

Date: $08 / 12 / 99$

Approved by:

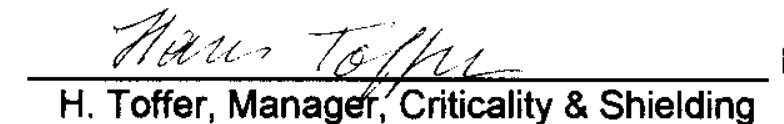

Date:

$8 / 16 / 43$

H. Toffer, Manager, Criticality \& Shielding

\section{INTRODUCTION AND SUMMARY}

This analysis resolves an apparent discrepancy between two different requirements of the Central Waste Complex and 200 Area Low-Level Burial Grounds Criticality Prevention Specifications (CPS-SW-149-00002 and CPS-SW-149-00003, respectively). The analysis is being performed to enable Solid Waste Management to accept a specific package from Bettis Laboratories. This package meets the requirements of Section 2.1.1 in that the total fissile content of the drum is less than $200 \mathrm{~g}$ and the fissilo natis ival occupies greater than $20 \%$ of the container volume. The package may not appear, however, to meet the requirements of Section 2.1.5 for maximum enrichment of uranium bearing waste, as will be described below.

Based on this analysis for the Eettis crum package, the waste is shown to be critically safe under all conditions for which the 55-gallon drums $(17 \mathrm{C}, 17 \mathrm{H}$, or UN1A2) specification applies. This package can be accepted under the 55-gallon drum limitations on tre 8iantive of tissile materal. No change to the CPS is required to stere has of um.

\section{DESCRIPTION OF CONTAINER AND PACKAGING}

The container of waste from Bettis consists of a 55-gallon drum (17C, 17H, or UN1A2), in which are contained 24 smaller containers ( 8 inch juice cans). One of the small cans contains $2.45 \mathrm{~g}$ of uranium oxide powder enriched to $9758 \% 235 \mathrm{U}$. The remaining 23 small cans contain a to a $80190 \% \mathrm{~g}$ of uranium with enrichments varying between $2.6 \%$ and $16 \% 2 \% 235 \mathrm{U}$. Total amount of $235 \mathrm{U}$ in the entire container (55-gallon drum) is $81.25 \mathrm{~g}$. Figure 1 depicts the details of the fissile material and containers in the Bettis waste shipment evaluated.

\section{APPLICABLE CRITICALITY PREVENTION SPECIFICATIONS}

Two specific criticality limits could apply to the Bettis package. The first is Section 2.1.1 (CPS-SW-149-00002) which allows $200 \mathrm{~g}$ of tissie nateril in a 55-gallon drum, if the fissile

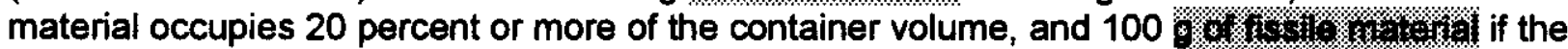
fissile material occupies less than 20 percent of the container volume. The second limit which could apply is Section 2.1.5 (CPS-SW-149-00002) which sets maximum amounts of uranium based on enrichment. Of most significance to the Bettis package is the or 8 limit that $\$ p$ ectiles 
a $75.0 w \%$. Given the specific situation, this latter limit is excessively conservative, as will be shown below.

\section{EVALUATION OF LOADING LIMITS}

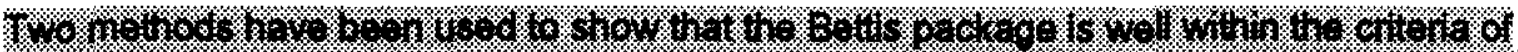

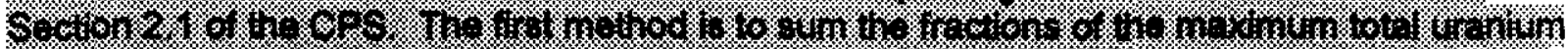

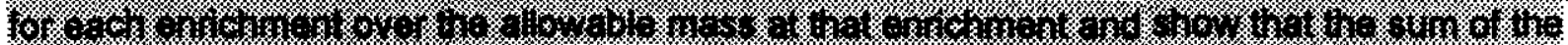

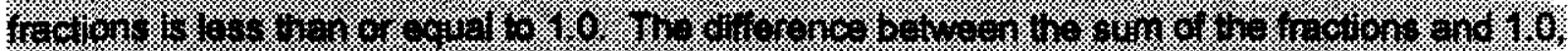

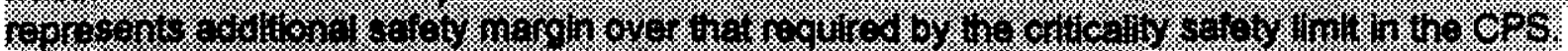
H.

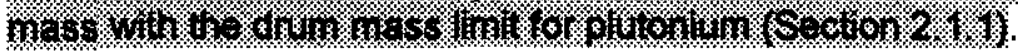

\subsection{Sum of Fractions}

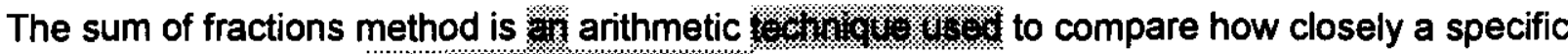

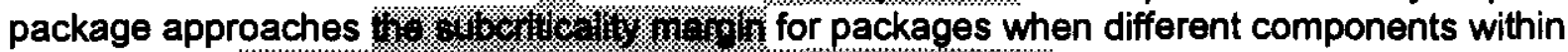
that package 3 . criticality and engineering in determining category 1 and category 3 limits for waste matrices based on limits for individual radionuclides. In this case the sum of the fractions 1.85 .2 to

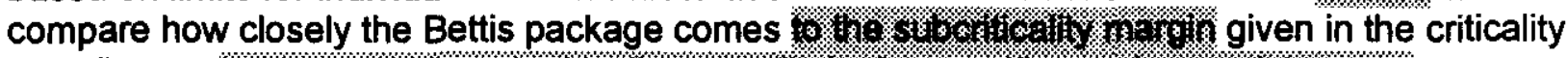

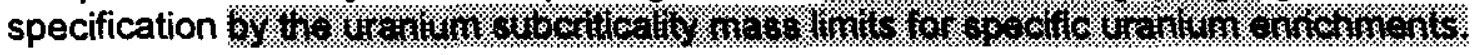

The sum of fractions method is used in the following manner. The total quantity of component $A$ is divided by the limit for component $A$, yielding fraction $A$. Similarly for all other components, yielding a fraction for each component. The sum is then taken of all the fractions. If the sum of the fractions is greater than 1 then the limit has been exceeded. If the sum of the fractions is less than or oximo 1 o 1 then the limit has not been exceeded.

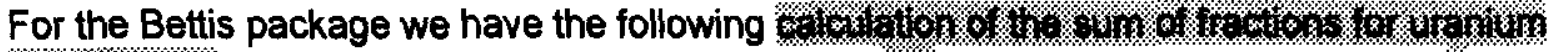

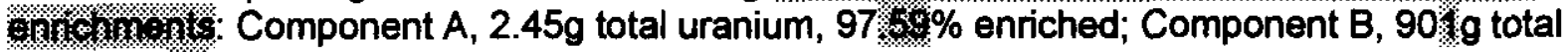
uranium, $20 \%$ enriched. This is conservative for component $B$ because the actual enrichment ranges from $2.5 \%$ to $16 \%$. $\%$. Based on the fact that there are only $81 / 2 \%$ of $235 \mathrm{U}$, average enrichment of component $B$ is closer to $9 \%$. The subcriticality limit for component $A$ is $180 \mathrm{~g}$ total uranium. The subcriticality limit for component $B$ is $1200 \mathrm{~g}$ total uranium.

Fraction $\mathrm{A}$ :

$=2.45 \mathrm{~g} / 180 \mathrm{~g}=0.0136$.

Fraction B:

$=90 \% \mathrm{~g} / 1200 \mathrm{~g}=0.750 \%$

The sum of the fractions:

$=0.7500+0.0136=0.76 \%<1$

By the sum of the fractions: the Bettis package is Witwing the subcriticality limits given for uranium bearing waste. 
HNF-SD-SQA-CSA-20395, Rev. 1

Page 3

\subsection{Comparison to allowable Pu gram loading in a 55 gallon drum}

The CPS allows 55 gallon drums which contain $200 \mathrm{~g}$ fissile material if the material occupies greater than $20 \%$ of the container volume, and $100 \mathrm{~g}$ fissile material if the material occupies less than $20 \%$ of the container volume.

The Bettis waste package contains a total of $81.25 \mathrm{~g} 235 \mathrm{U}$, which will be distributed over more than $20 \%$ of the container volume. This is less than the $200 \mathrm{~g}$ limit. As an extra conservatism, it is also less than the $100 \mathrm{~g}$ limit. This comparison also neglects the fact that in the Bettis

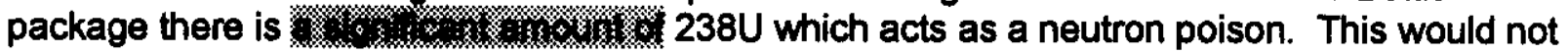
be the case if the $200 \mathrm{~g}$ fissile material were all plutonium.

\section{REVISION OF CPS LIMITS}

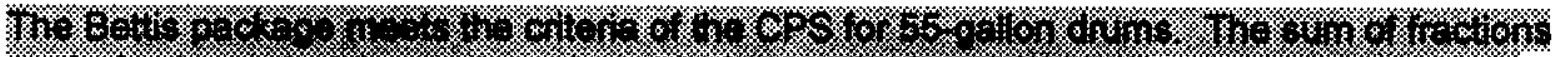

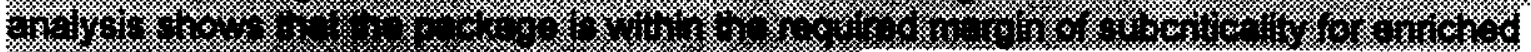

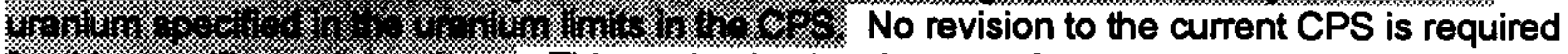

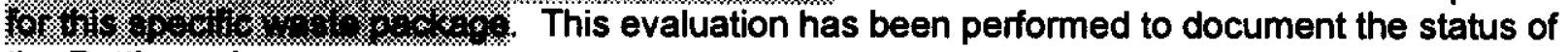
the Bettis package.

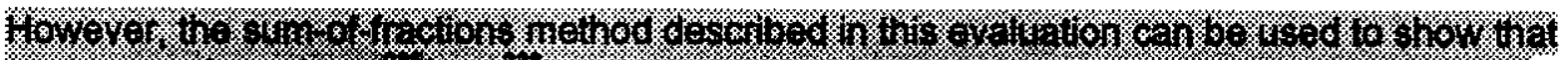

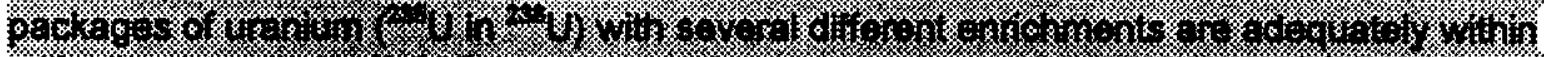

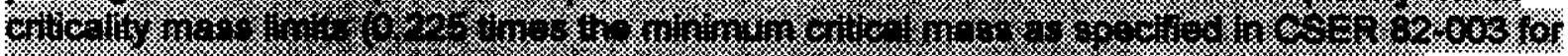

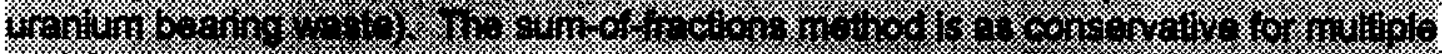

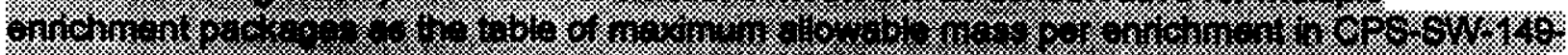

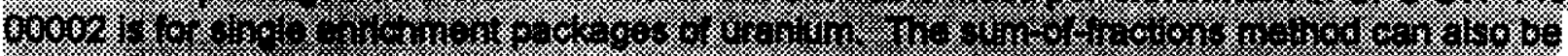
3.

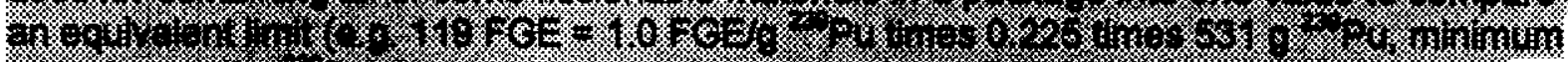

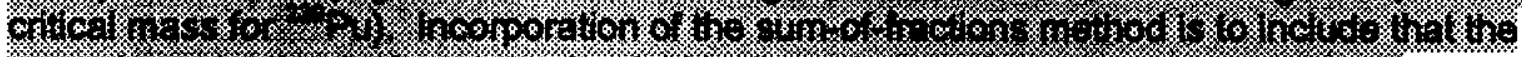

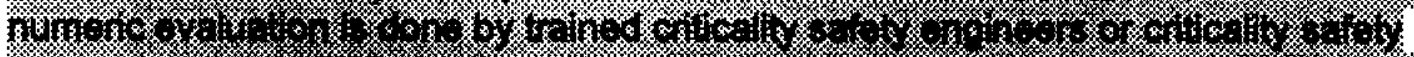

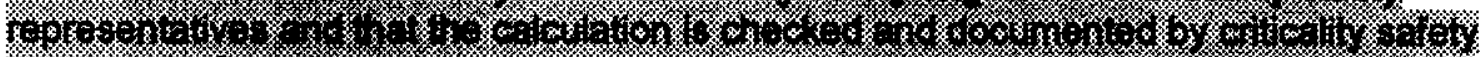

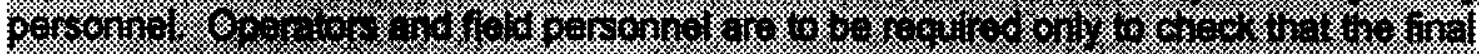

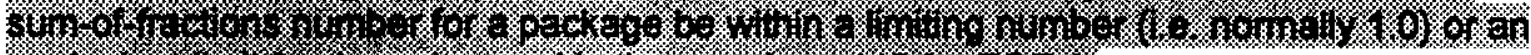
6.

\section{REVIEWER COMMENTS}

\subsection{E. M. Miller (Rev. 0, 1995)}

The independent technical review of the report, "CSER 95-007, ACCEPTABILITY OF BETTIS LABORATORIES WASTE SHIPMENT TO WHC SOLID WASTE" was done by E. M. Miller, a criticality engineer in the Consequence Analysis group. His comments are as follows.

This CSER justifies the acceptance of a drum containing more total uranium than is allowed by CPSs CPS-SW-149-00002 and CPS-SW-149-00003 for the highest uranium enrichment in the container, because the amount of highly enriched uranium is so small as to be insignificant for a criticality assessment. This reviewer concurs completely with the conclusion and approach taken for these small amounts of uranium that have large margins of safety. Note that if all the 81.25 grams of $U-235$ were in $97 \%$ enriched uranium $(81.25 \mathrm{~g} / 0.97=83.5 \mathrm{~g})$, the total amount of uranium would be less than half the limit of 180 grams total uranium at an enrichment of greater than $75 \%$ specified in the CPSs. This barrel's reactivity addition to a storage array is far less than the $\mathbf{2 0 0}$ or $\mathbf{1 0 0}$ grams fissile material allowed by the CPSs. 
HNF-SD-SQA-CSA-20395, Rev. 1

Page 4

\subsection{J. Greenborg (Rev. 1, 1999)}

$\mathrm{J}$. Greenborg, a criticality engineer in the Criticality and Shielding group, did the independent technical review of CSER 95-007, Rev. 1. His comments are as follows.

This reviewer also concurs completely with the conclusions, approach and the margin of safety. The models and the calculations based on the data in this document were checked and found correct. The subject container of this document was not delivered to Hanford, as such, the original source information is not available, and cannot be checked for consistency. The technical peer review checklist for this review is attached.

\section{REFERENCES}

SD-SQA-CSA-20121

SD-SQA-CSA-20101

SD-SQA-CSA-20130

"CSAR 80-021, Packaging, Storage and Disposal of Solid Waste (55-gallon drums, Unrestricted H/Pu Only)."

"CSAR 80-021, Addendum 5, 55-Gallon Drums and Boxes in Above Ground (Surface) Storage."

"CSAR 82-003, Packaging, Storage and/or Disposal of Solid Waste (Burial Containers and Uranic Burial)."

SDAR-69-1G-7-M-0401

Applicable Storage Disposal/Approval Record. 
MSF-069 Uranium Enriched Mixed Waste

HNF-SD-SQA-CSA-20395, Rev. 1

Page 5

FIGURE 1

\begin{tabular}{|c|c|c|}
\hline Container ID & $\%$ U-enr & $\mathrm{Gm} \mathrm{U-235}$ \\
\hline $23061-01$ & 9.40 & 7.89 \\
\hline $23061-03$ & 9.40 & 1.51 \\
\hline $23061-04$ & 9.40 & 0.63 \\
\hline $23061-06$ & 9.87 & 3.47 \\
\hline $23040-01$ & 9.40 & 0.50 \\
\hline $23040-02$ & 9.40 & 1.12 \\
\hline $23040-03$ & 9.40 & 0.72 \\
\hline 23183-01 & 5.92 & 3.53 \\
\hline 23183-02 & 5.86 & 4.21 \\
\hline $23183-03$ & 5.85 & 0.57 \\
\hline $23170-04$ or $\mathrm{DI}-37$ & 5.85 & 2.14 \\
\hline $23170-05$ or $\mathrm{Dl}-38$ & 5.86 & 6.45 \\
\hline $23170-06$ or $\mathrm{Dl}-39$ & 5.98 & 4.74 \\
\hline $23180-01$ & 2.66 & 1.12 \\
\hline $23180-02$ & 2.66 & 0.59 \\
\hline $15775-01$ & 16.21 & 8.11 \\
\hline $15775-02$ & 16.21 & 1.25 \\
\hline $15775-03$ & 16.21 & 0.50 \\
\hline $23179-01$ & 16.72 & 5.67 \\
\hline $23179-02$ & 16.72 & 2.05 \\
\hline $23179-03$ & 16.72 & 1.06 \\
\hline $18077-02$ & 11.04 & 7.53 \\
\hline $18077-01$ & 11.03 & 13.41 \\
\hline \multirow[t]{2}{*}{ DI-252 or KD103-01 } & 97.59 & 2.39 \\
\hline & TOTAL & 81.25 \\
\hline
\end{tabular}


FLUOR DANIEL NORTHWEST

TECHNICAL PEER REVIEWS

\section{CHECKIST FOR TBCHNICAL PEER REVISW}

Document Reviewed:

Title:

Author:

Date:

Scope of Review:

Yes No* NA

[X] [ ] [ ]"* Previous reviews complete and cover analysis, up to scope of this review, with no gaps.

[x] [ ] [ ] Problem completely definod.

[ 1 [ ] [X] Accident scenerios developed in a clear and logical manner.

[X] [ ] [ ] Necesary ascrumptions explicitly statod and supported.

[ ] [ ] [X] Compoter codes and deta files documented.

[x] [ ] [ ] Data nsed in calculations explicitly stated in document.

[ ] [ ] D Data checked for consistency with original source informstion as applicabie.

[X] [ ] [ ] Methematical derivations checked including dimensional consistency of reaults.

K] [ ] [ ] Models eppropriate and usod within range of validity or use outside range of astablishod validity justifiod.

W] [ ] [ ] Hand calculations chocked for errors. Spreaduheet results should be treated excactly the sume as hend calculations.

[ ] [ ] $\infty$ Softwere input correct and consistent with document reviowed.

[ ] [ ] [x] Softwere outpot consistent with input and with results reparted in document reviewed.

[X [ ] [ ] Limits/criteria/guidalines appliod to analysis results are appropriate and reforenced. Limits/criteria/guidelinos chockod against references.

[X] [ ] [ ] Safety margins consistent with good engineering practioes.

[X [ ] [ ] Conclusions consistent with analytical results and applicable limits.

X] [ ] [ ] Results and conchusions address all points required in the problem statement.

[x] [ ] R* Review calculations, comments, and/or notes are attached.

[X] [ ] [ ] Truceability

[X] [ ] [ ] Dociment approved (i.e., the reviewer affirms the tochnical accuracy of the document).

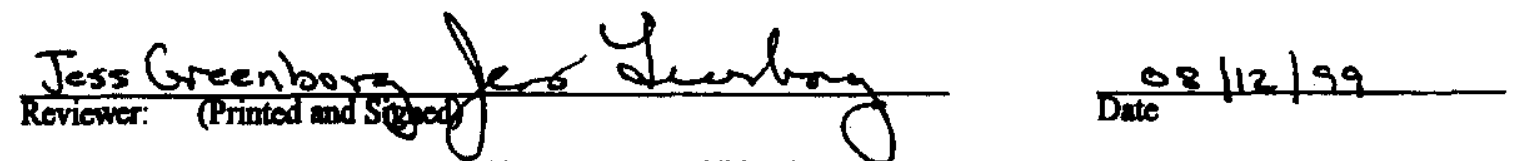

" All "NO" responses unust be oxplained below or on an edditional page.

** Any oaloulations commente, or notes genereted as part of this review abould be signect datod and atteched to this ohocklist. Such material should be labeled and rocorded in such a manner ss to be intelligible to a technically qualified third party. 